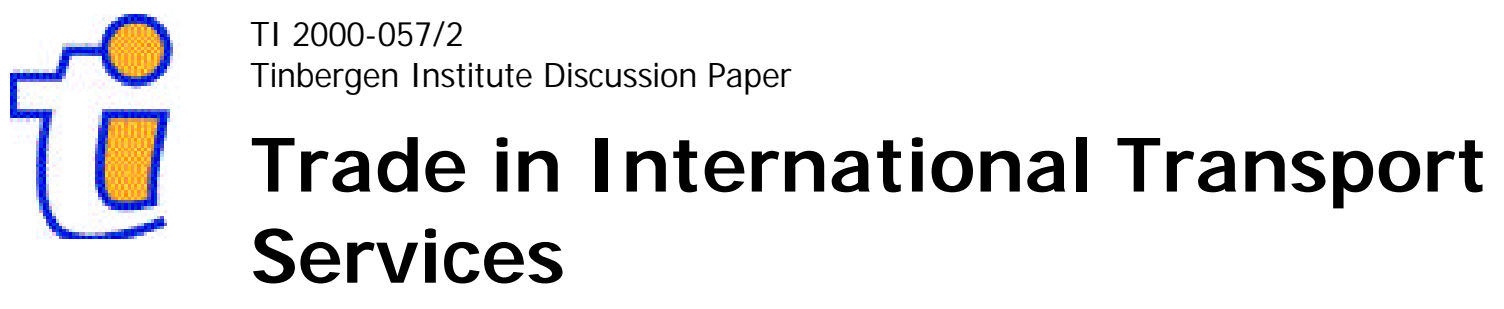

J oseph Francois

Ian Wooton 
Tinbergen Institute

The Tinbergen Institute is the institute for economic research of the Erasmus Universiteit Rotterdam, Universiteit van Amsterdam and

Vrije Universiteit Amsterdam.

Tinbergen I nstitute Amsterdam

Keizersgracht 482

1017 EG Amsterdam

The Netherlands

Tel.: +31.(0)20.5513500

Fax: $\quad+31 .(0) 20.5513555$

Tinbergen I nstitute Rotterdam

Burg. Oudlaan 50

3062 PA Rotterdam

The Netherlands

Tel.: $\quad+31 .(0) 10.4088900$

Fax: $\quad+31 .(0) 10.4089031$

Most TI discussion papers can be downloaded at

http://www.tinbergen.nl 


\title{
TRADE IN INTERNATIONAL TRANSPORT SERVICES: THE ROLE OF COMPETITION
}

\section{Joseph Francois*}

\author{
Tinbergen Institute and CEPR
}

\section{Ian Wooton}

\author{
University of Glasgow and CEPR
}

\begin{abstract}
We are concerned with trade in transport services (not cabotage but rather international shipping, transport, and related logistical services) and the importance of competition and market structure in the sector. We examine implications of liberalization for profits, trade, and national gains from trade. Though past GATS maritime negotiations involved the maritime nations, we also flag interests of consuming nations (particularly poorer developing countries). We further illustrate issues raised in the analytical section through a computational example, to provide a rough sense of orders of magnitude and the importance of the issues raised for basic gains from improved market access.
\end{abstract}

JEL Codes: F12, F13, F23

Keywords: services trade, trade liberalization, market access, imperfect competition

\section{Revised, June 2000}

* This paper was prepared for the CEPR/NBER International Seminar in International Trade, Cambridge, MA, June 1999. We are grateful for the helpful comments of participants, especially those of our discussant, Drusilla Brown. We are also indebted to Leonard Cheng, Gregg Huff, and Siri Pettersen Strandenes for their suggestions. This paper was revised while Wooton was visiting the Economic Policy Research Unit, University of Copenhagen and he wishes to thank them for their hospitality. 


\section{INTRODUCTION}

The conclusion of the Uruguay Round in 1993 and the subsequent launching of the World Trade Organization marked an important shift in the multilateral trading system. The postWorld War II trading regime (commonly referred to as GATT 1947) was focused on the rules governing merchandise trade between industrial countries. In contrast, while the new WTO system includes a revamped GATT (now called GATT 1994), it also includes a parallel institutional framework devoted to services trade--the General Agreement on Trade in Services (GATS). It also appears to include a deeper commitment by the developing countries to participate in the multilateral trading system.

While the Uruguay Round included negotiations on market access in several service sectors, these negotiations proved problematic, even by Uruguay Round standards. ${ }^{1}$ In the end, the negotiators declared victory and went home, agreeing to reschedule (i.e. extend) service negotiations for some time after the victory parties. With service negotiations decoupled from simultaneous negotiations in other sectors, the negotiating game changed. ${ }^{2}$ In the end, some of these negotiations (like financial services) did conclude successfully. The same cannot be said for maritime services.

Sticking points in the maritime negotiations included cabotage restrictions and national preference schemes. In retrospect, given that the industry is largely protected from competition on domestic routes (cabotage) and exempted from antitrust rules for international routes, it is not surprising that the industry and its negotiating representatives resisted

\footnotetext{
${ }^{1}$ It is not too far off the mark to characterize initial GATS negotiations as an exercise in defining precisely what was being negotiated. The result is a mix of traditional cross-border "trade" along with establishment issues related to rights of establishment (i.e., "investment"). Together, these imply an extension of the basic GATT concept of market access to cover both trade and investment commitments related to deliverable services.

${ }^{2}$ As Finger (1983) would say, the situation changed to one where a positive decision could be taken by a limited group of participants.
} 
liberalization. $^{3}$ The U.S. delegation, for example, was backed by a very vocal domestic industry, and stood strongly opposed to making market access commitments in the sector, especially with regard to cabotage. ${ }^{4}$ While the extended negotiations on maritime services lasted two years beyond the end of the Uruguay Round, they were finally laid to rest on 28 June 1996 when WTO Member delegations agreed to suspend negotiations. They deferred them again, this time until the next round of comprehensive service negotiations, scheduled to begin in the year 2000 .

This paper is concerned with trade in international transport, logistics, and related services. While our discussion will often be couched in terms of the maritime sector, the basic analytics apply to the full chain of services required to complete the transactions that turn exports into imports at the dock. The paper itself is divided into three parts. The first offers a brief overview of the structure of the maritime industry. This includes some discussion of patterns of ownership and demand, discussion of the institutionalized cartels that dominate the industry, and the (limited) available evidence on the effect of these cartels on price. Armed with stylized facts, we then develop an analytical model that illustrates some of the basic issues at stake with liberalization of maritime services trade. This involves not only the implications for the profits of the industry (one issue that has certainly been well represented in past negotiations), but also the implications for levels of trade and national

\footnotetext{
${ }^{3}$ In the early 1990s a series of studies by the USITC (1993) and also the Institute for International Economics (Hufbauer and Elliot 1994) came out estimating the cost of U.S. cabotage restrictions. The initial reaction of the U.S. Maritime Administration was to claim that trade economists misunderstood the issue. As argued at USITC hearings, the basic logic was "There is no trade in cabotage services. Hence there can be no cost of trade protection." The logic of the industry when dealing with their regulators is one of "price stability" and quantity management. Even within the United Nations, the UNCTAD reports on maritime transport (see UNCTAD 1992 for example) devote considerable discussion to the problem of oversupply. Viewed another way, such oversupply makes it difficult for cartels to maintain desired pricing structures.

${ }^{4}$ Officially, "the U.S. delegation has taken the position that the United States already maintains a high level of access in its maritime sector-as indicated by the 96 percent of our foreign trade that is carried in foreign-flag vessels - and needs to maintain its support programs, small as they are, to help assure the availability of national flag tonnage for sealift purposes... The decisions to suspend the
} 
gains from trade. Since the past negotiations involved the maritime nations themselves, we think it also appropriate to flag the interests of the consumer (i.e., non-maritime) nations. These include the poorer developing countries. Finally, we supplement the analytics with a numeric example. The numerics serve two functions. One is to illustrate the issues raised in the analytical section of the paper through example. The other is to place this example in the context of actual numbers, to provide a crude gauge of the relative magnitudes of the effects discussed.

\section{THE INTERNATIONAL SHIPPING INDUSTRY}

\subsection{Market structure}

In the maritime world, the oceans are populated with shipping conferences. Conferences meet regularly to set rates, analyze market conditions, and assess other developments like fuel prices and port charges. A recent development has been supplementation of conferences with "talking agreements" and similar arrangements. As of the end of 1998, one of these agreements, the Transpacific Stabilization Agreement, controlled about 86 percent of U.S. waterborne trade with Asia. ${ }^{5}$ Another cartel, the Trans-Atlantic Conference Agreement (TACA), controls a comparable share of North Atlantic trade. The shipping press characterizes the Pacific as a region where individual shipping lines are prone to "break ranks" on prices (apparently a bad thing) unless held in check by the cartel rules adopted by conference lines (apparently a good thing).

In the case of U.S. routes (a non-trivial share of world trade), the job of policing the cartels is carried out by the U.S. Government. Individual shipping lines are subject to punitive fines, imposed by the Federal Maritime Commission (FMC), if they break ranks

negotiations was strongly supported by the U.S. Maritime Administration and other members of the U.S. delegation.” (USDOT 1998).

${ }_{5}^{5}$ Once concluded, this particular agreement announced a $\$ 300$ per 40 -foot container rate increase for May 1998. (The Portal on-line, January/February 1998). 
with the published schedule of rates. To promote their activities, conferences are give exemptions from antitrust laws. ${ }^{6}$ Transparency of pricing is enforced (including required internet publication of rates) to ensure that price fixing is adhered to. "The FMC's role in enforcing filed rates implies that conference agreements are policed by an outside agency at no cost to the conference. Thus, the tariff filing and enforcement requirements potentially facilitate the exercise of conference market power." (Clyde and Reitzes, 1995).

Different institutional arrangements stand as monuments to multilateral and regional efforts to regulate shipper arrangements. Notable is the UNCTAD Code of Conduct for Liner Conferences (UNCTAD 1975, TD/CODE/13). The United States never ratified the code, while European countries demanded exemptions (known as the Brusselss package) from crucial parts of the code. The consensus is that, at best, "the UNCTAD Code of Conduct occupies a very limited part in the regulatory framework of liner shipping." At a regional level, the United States has allowed the TACA to extend its anti-trust exemption up/downstream to include intermodal rate fixing, while the EU has not yet set policy on intermodal rate fixing. (Veenstra 1999, Chapter 3).

Despite the fact that this sector is literally at the center of world trade, the economic impact of these arrangements on the gains from trade and their interaction with trade policy has not been emphasized in the literature limited. ${ }^{7}$ Rather the literature, starting with Koopmans (1939) and Tinbergen (1959), is more narrowly focused on the determination of shipping rates and the role of market structure. This includes Deakin and Seward (1973),

\footnotetext{
${ }^{6}$ The rational for such exemptions is that conferences provide price stability and limit uncertainty regarding available tonnage. This includes both U.S. and Canadian law. The U.S. Shipping Act of 1984 eliminated the public interest standard of antitrust law, reversing a trend toward greater antitrust scrutiny. As a result, conference agreements are not subject to an approval process, but instead can be challenged by the FMC. The FMC has never attempted to stop formation of a conference (Clyde and Reitzes 1995). There have been some recent initiatives to reform these laws, though the maritime press has argued that these "reforms" may actually strengthen current antitrust exemptions.

${ }^{7}$ An exception is Getzler (1997).
} 
Heaver (1973), and Talley and Pope (1985). Sjostrom (1992) argues that much of this recent literature on shipping rates is actually inconclusive, because of incorrect model specification.

Clyde and Reitzes (1995) examine shipping rates filed by ocean liner conferences with the FMC between 1985 and 1988. They look for evidence as to whether the rate structure in ocean shipping markets is based on costs, the exercise of market power by conferences, or the exercise of market power by firms in a manner unrelated to the conference system. They conclude that "some aspects of the conference system may contribute to higher shipping rates, particularly when the conference has a sizable market share." They also find that "conferences do not act as perfect cartels maximizing the joint profits of their members." This last finding is consistent with the tone of the maritime press, which has described constant efforts (aided and abetted by national maritime administrations) to introduce or restore price discipline in the face of the temptation for individual members to cheat. $^{8}$

Sjostrom (1989) suggests that these shipping conferences may exist, not as monopolizing cartels, but to ensure that shipping services are provided in a market in which there is no competitive equilibrium. In a market with avoidable fixed costs, the core may be empty and he argues that collusion imposes an equilibrium where otherwise none would exist. He tests this hypothesis against that of the conference being a cartel and finds some support for the theory of the core.

\footnotetext{
${ }^{8}$ The maritime press also offers anecdotal evidence on price discrimination. For example, The Portal on-line (October 1998) focuses on the example of the cost of moving a container through ports on the U.S. East Coast. In theory, the cost should be the same regardless of destination. However, while it cost $\$ 420$ in 1998 to move a 40 foot container under Trans-Atlantic Agreement contracts, it estimates that it cost $\$ 600$ in 1998 to move the same container through the same facilities under Mediterranean conference contracts, and \$550 under Inter-American Freight Conference contracts.
} 


\subsection{Shipping margins vs. import tariffs}

In terms of relative costs to trade, shipping margins are now far more important to many countries than tariff barriers. Successive rounds of trade liberalization under the auspices of the GATT/WTO have made dramatic reductions in average tariffs, while regional arrangements, such as the EU and NAFTA have reduced trade barriers further still.

This contrasts with shipping margins of over eight percent. (See Ajmadi et al., 1996, for more on this point.) Many countries would gain far more, in terms of market access, from squeezing shipping margins than from a further reduction in OECD tariff rates. We will return to this point in the computational section of the paper).

\section{A THEORETICAL MODEL}

We now turn to an analytical model of trade with transport costs. The framework we develop has interesting policy implications. For example, we show that it is possible to use shipping cartels as a second-best instrument for manipulating the terms of trade. Hence, with European preference schemes, one can easily imagine a situation where shipping cartels to Africa would allow the partial recapture of market-access concessions made under preferential trading schemes. The rents would be split with the cartels. If the cartels are themselves European, the recapture is complete. In a more general sense, the combination of high shipping margins and concentrated ownership (see UNCTAD 1992) suggests a strong consumer (i.e., non-maritime) country interest in an effective, pro-competitive maritime agreement under the GATS.

The message about competition actually covers the whole logistics chain. Any choke point, in terms of competition, in the chain of services that facilitates trade can lead to the type of result developed here. If not resulting from the shipping operations themselves, it may arise due to corrupt port management or a monopoly on handling and loading. 


\subsection{The basic model}

Much of the literature on trade and transportation has been focused on general-equilibrium patterns of trade and on the uniqueness of equilibrium. (See for example Wegge 1993). As we are concerned instead with market structure, we buy ourselves a great deal of analytical simplicity by working with a reduced-form, dual structure. The formal model that emerges provides a framework for both our analytical discussion of equilibrium given market power in the transport sector and for the calculation of welfare effects in the numerical section of the paper.

We start by defining the general equilibrium for a small country in terms of dual expenditure and revenue functions. As will become evident, for individual product markets (more generally for standard 2-good models and alternatively for the stylized representation of exports and imports of composite goods), this approach allows us to illustrate generalequilibrium results through the familiar geometric tools normally associated with partialequilibrium models. (See Martin, 1997; Francois and Hall, 1997.) The value of output is defined by the function $g(p, v)$ and the expenditure function by $e(p, u)$ :

$$
\begin{gathered}
g(p, v)=\max _{h}(p \cdot h \mid(h, v) \text { feasible }) \\
e(p, u)=\max _{c}(p \cdot c \mid f(c) \geq u)
\end{gathered}
$$

In equations (1) and (2), $e(p, u)$ is the expenditure required to achieve the level of utility $u$ from consumption of $c$ at the vector of domestic prices $p$; while $g(p, v)$ is the gdp function indicating the maximum revenue from production (of $h$ ) that can be generated with resource endowments $v$ at domestic prices $p$. For notational simplicity, it is convenient to combine equations (1) and (2) into a net revenue function

$$
z(p, u, v)=e(p, u)-g(p, v)
$$


The vector of domestic demands for output is given by $e_{p}$, the first derivative of $e(p, u)$ with respect to $p$, while domestic supplies are represented by $g_{p}$. The trade matrix (net imports $M$ ) is then the first derivative of the net revenue function with respect to price:

$$
M(p)=z_{p}(p, u, v)=e_{p}-g_{p}
$$

The gap between the domestic and border prices, $\left(p-p^{*}\right)$, is the tax on trade, so that tradetax revenues are given by $\left(e_{p}-g_{p}\right)\left(p-p^{*}\right)$. In discussing the impact of changes in the trade regime, we work with a second-order Taylor-series expansion of this system. This amounts to focusing exclusively on the first and second derivatives of $z$ and amounts to assuming that import demand and export supply are (approximately) linear.

Within this framework, we emphasize the trade in an export commodity that is produced in the export market and then shipped, at some cost, to the import market where it is sold (i.e., exchanged for imports). Let the quantity of the export commodity traded be $q$. Producers of the good are assumed to be small, perfectly competitive firms located in one or several countries. The industry supply curve for exports is linear in producer prices $p_{p}$ :

$$
p_{p}=a+b q
$$

The shipping industry provides the service of transforming exports into imports at the dock. ${ }^{9}$ This service is provided at a price $\sigma$ (the shipping margin, essentially the difference between the f.o.b. and c.i.f. price) that depends on competitive conditions in the shipping industry. ${ }^{10}$ We assume that the shipping industry is imperfectly competitive, with $n$ identical, profit-maximizing firms in competition with rival shipping firms. The shippers have large

\footnotetext{
${ }^{9}$ In this paper, there is only one stage of intermediation (shipping). In our companion paper, Francois and Wooton (2000), we consider the implications of having several intermediaries in moving the good from producer to consumer.

${ }^{10}$ Note here that the relevant cost is that of full transformation of exports into imports, which includes the shipping margin on the outbound and inbound journey. Analytically, we solve here for a total value for this margin, though of course it may technically be shared across the inbound and outbound journeys.
} 
fleets that can be used on many different global shipping routes. From this stock, they choose to allocate a certain quantity to service this particular trade. Thus the shipping firms compete in quantities.

Consumers in the foreign market have a linear inverse-demand function for imports, relating the price they are charged $p_{c}$ to the quantity traded $q$ as follows:

$$
p_{c}=x-y q
$$

We assume that the good faces a import barrier in the form of an ad valorem tariff of $t .^{11}$ The price paid by consumers in the destination consequently exceeds the price received by producers as a result of both the shipping margin and the tariff $p_{c}=(1+t)\left(p_{p}+\sigma\right)$.

Rewriting this as an expression for the shipping margin, we get:

$$
\sigma=p_{c} /(1+t)-p_{p}
$$

The total revenue of a representative firm $i$, producing quantity $q_{i}$, is $\sigma q_{i}$. We assume that the shipping firms are identical and behave as Cournot competitors. Substituting (5), (6), and (7) into total revenue yields an expression for the perceived marginal revenue of a firm:

$$
M R_{i}=\frac{x}{1+t}-a-\frac{(1+s)[(1+t) b+y]}{s(1+t)} q_{i}
$$

\footnotetext{
${ }^{11}$ Brander and Spencer (1984) examine the optimal trade restriction for an importing country when faced with an imperfectly competitive supplier. They show that, dependent upon demand conditions, this policy may tax the form of a tariff or a subsidy. When demand is linear (as is the case in our model), Brander and Spencer find that a positive tariff is the appropriate instrument, but this will change with other configurations of demand. Their model has constant marginal costs for the supplier. In contrast, because we assume increasing opportunity costs for exports, our shippers face increasing marginal costs. As a result, a tariff becomes the preferred instrument for a wider range of cases than in the Brander and Spencer model. In any event, our focus is not on rediscovering the optimal strategic interactions between large players. Instead, we choose to consider the implications for the market of exogenous reductions in tariffs resulting from a round of trade liberalization.
} 
where $s \equiv 1 / n$ is the market share enjoyed by each of the shipping firms. We assume that the real costs of shipping (insurance and freight) are constant, the marginal cost of transport is: ${ }^{12}$

$$
M C=c
$$

Solving (8) and (9) provides the equilibrium quantity of the good supplied:

$$
q=\frac{x-(a+c)(1+t)}{[b(1+t)+y](1+s)}
$$

while the equilibrium shipping margin is ${ }^{13}$ :

$$
\sigma=\frac{x s+(1+t)(c-a s)}{(1+t)(1+s)}
$$

The associated prices of the good for consumers and producers, respectively, are:

$$
\begin{aligned}
& p_{c}=\frac{x[b(1+t)(1+s)+y s]+y(a+c)(1+t)}{[b(1+t)+y](1+s)} \\
& p_{p}=\frac{b[(a s-c)(1+t)+x]+a y(1+s)}{[b(1+t)+y](1+s)}
\end{aligned}
$$

If $s=1$, the shipping industry is monopolised. As $s$ becomes smaller, the firms' perceived demand for the good becomes more elastic and they lose market power. With $s$ close to zero, each firm has an infinitesimal share of the market and behaves competitively. There are two elements to the market power of a firm. Firstly, they charge consumers a price that exceeds the shippers' marginal costs. In addition, the shippers exploit their monopsony power with producers. The producers have increasing marginal costs and, consequently, the shippers restrict their purchases.

\footnotetext{
${ }^{12}$ We do not consider changes in these real costs of transport, our focus being on the additional margin charged by shipping firms as a result of their market power. Hummels (1999) investigates the issue of whether transport costs have declined and concludes that they have not.

${ }^{13}$ This shipping margin is essentially the "best response" of the shipping industry to the import tariff. We more closely examine the strategic interplay between agents in Francois and Wooton (2000).
} 


\subsection{Effects of increased competition}

We simulate the effects of increasing the level of competition through a change in the number of firms in the shipping industry $n$. (Such increased competition may follow from GATSrelated liberalization of the shipping route itself, or from related liberalization somewhere else in the logistics chain.) If $n$ rises, the market share $s$ of each incumbent firm declines. They will perceive their market demand to be more elastic and will consequently behave more competitively. If, however, the number of firms were to fall, the industry will become more concentrated and the remaining firms will exercise the increased power from a growing market share.

Of course, there need not actually be a change in the number of firms. Rather, $s$ can instead be viewed as an indicator of the degree of competitiveness in the shipping market. In this interpretation, a fall in $s$ reflects a more competitive environment (as $n$ becomes larger, market shares decline and the shippers' margin gets closer to marginal cost). This could occur if the shipping conference's influence in maintaining common rates were to decline or if its activities became subject to antitrust rules. An increase in $s$ would indicate that the conference was exerting greater influence in the market, resulting in more collusion.

Figure 1 shows the effects of changing $s$ on prices, quantities, and profits. As the shipping industry shifts from behaving as perfect competitors to acting as a monopolist, the consumers pay an increasing price and the volume shipped declines. Given that less of the product is being demanded, the price received by the producers falls. The (shaded) growing gap between the producer and consumer price is $\sigma$, the margin captured by the shippers, and this rises monotonically from zero as the industry becomes increasingly concentrated. Thus, when the industry behaves competitively, the shipping margin equals $c$, the marginal cost of shipping. The margin reaches its highest level when there is complete collusion and the shippers fully exploit their monopoly power with both producers and consumers. 


\subsection{Benefits of trade liberalization}

How does the tariff affect the trading situation? With a competitive shipping industry, the beneficiaries of trade liberalization would be the consumers in the importing country and the exporting producers. With a less-than-perfectly-competitive shipping industry, the benefits of the more liberal trade regime are partially captured by the shipping firms. Figure 2 illustrates the equilibria that arise with a duopolized shipping industry for various levels of tariff. $^{14}$

As the tariff is reduced, the quantity traded rises, as the consumer price has declined. This rise in demand results in a higher price being received by the producers. However, the benefits of the trade liberalization are not fully passed through to producers and consumers. The shippers are able to take advantage of the more liberal trade regime, replacing part of the trade-tax wedge (between consumer and producer price) by one of their own, a greater monopolistic markup. As the tariff continues to fall, the shipping firms receive a larger margin over their marginal costs, resulting in increasingly large profits.

The relationship between the concentration of the shipping industry, the tariff barrier, and the optimal shipping margin is illustrated in a contour plot in Figure 3. The more concentrated the industry (or the stronger the cartel) and the lower the tariff barrier, the greater is the shipping margin

\section{A NUMERICAL EXAMPLE}

We now turn to a computational example, based on the analytical results derived above. We work directly within our theoretical framework in order to relate welfare changes to trade and the structure of the shipping industry. To do this, recall that from the point of view of exporters the impact of imperfect competition in the shipping sector is realized as a 
deterioration in the equilibrium terms of trade. A convenient approach to evaluating the welfare impact of such a terms-of-trade shock in general equilibrium is the balance-of-trade function (Lloyd and Schweinberger, 1988; Anderson and Neary 1992). Under this approach we estimate a money measure of the change in welfare resulting from the shock by evaluating the change in the balance of trade necessary to maintain constant utility (i.e., the net transfer needed to maintain welfare), given the change in realized relative border prices. A shock to the general equilibrium system that reduces domestic utility effectively increases the income needed to achieve a given level of utility, and hence requires a transfer from the rest of the world to maintain that utility level.

The balance of trade $B$ is simply the net revenue function defined in equation(3). That is,

$$
B=z(p, u, v)
$$

We can approximate the impact of our terms-of-trade-shock on welfare with a second-order Taylor series expansion of equation(13), obtaining the following for the producers:

$$
\Delta B=q \Delta p_{p}-\frac{1}{2 b}\left(\Delta p_{p}\right)^{2}
$$

We have implemented the system of equations defined in Section 3, supplemented by equation(14), as a simple computational model. We work with three stylized regional developing economies, based on average macroeconomic data for 1995. These data are presented in Table $1 .^{15}$

Our basic experiment involves a hypothetical full elimination of tariffs in export markets for each of these stylized economies (i.e., full, unconditional market access). We

\footnotetext{
${ }^{14}$ The figures for different numbers of shipping firms are qualitatively very similar, except in the case of competition when shipping industry profits are zero at all times and, consequently, all the benefits of trade liberalization accrue to the producers and consumers.

15 The full model, implemented both in Mathcad and as an Excel spreadsheet, is available upon request. Protection data are from Francois and Strutt (1999). Other data are from Center for Global Trade Analysis (1999).
} 
observe the shipping margins on these trades (the sum of the inbound and outbound differences between the c.i.f. and f.o.b. measures), but cannot determine whether the margins reflect the costs of transportation or are an artifact of the degree of market power that the shipping conferences enjoy. (We also miss the additional distribution/shipping margins associated with related costs inside the border.) Consequently, in our empirical exercise we assume a variety of specific market structures for the shipping industry, ranging from competition to perfect collusion (monopoly) and allocate the shipping margin between marginal costs and profits accordingly. The welfare effects of trade liberalization, assessed under these alternative assumptions about market structure, are provided in Table 2.

It can be seen from Table 2, panel A that the benefits of improved market access depend critically on the degree of competition in the shipping industry. At the one extreme, a competitive shipping sector implies a full pass-through of terms-of-trade improvements to the producers. In contrast, a more collusive industry is able to capture a significant share of the realized gains that follow from these changes in market access conditions. For example, in all cases, approximately one-half of the gains from full and unconditional market access can be lost by producers to the shipping industry when the latter is concentrated and fully exploits its market power, capturing part of these gains for itself. The related effects include smaller increases in trade volumes (Table 2, panel B), and a sharp rise in shipping prices (Table 2, panelC).

The message that emerges from these experiments is that, in terms of rough orders of magnitude, the competitive structure of the shipping industry is indeed an important issue. Realized gains from market access concessions depend critically on the pricing structure of the industry that facilitates trade. 


\section{SUMMARY AND CONCLUSIONS}

Our goal in this paper has been to examine the importance of market structure in the transport sector for the distribution of gains from trade and the benefits of trade liberalization. We have shown that the presence of an imperfectly competitive intermediary can have a significant effect on trade flows and the allocation of gains from trade. Trade liberalization in the absence of some form of deregulation of the shipping industry will not result in the increased benefits that would otherwise be imagined, as the shipping firms will grab a portion of the gains from trade.

Combining an analytical model with "real data," we have shown that the relative magnitude of these effects can be quite significant. Trade liberalization with the present trading climate can lead to shipping firms capturing a significant proportion of the benefits of multilateral trade concessions. This highlights the important relationship between trade and competition in the shipping sector itself (maritime, air, trucking, and related links in the logistics chain) and the gains from trade in other sectors. GATS negotiations in this area have important implications for multilateral efforts aimed more broadly at trade liberalization. 


\section{REFERENCES}

Amjadi, A., U. Reincke, and A.J. Yeats, 1996, "Did external barriers cause the marginalization of sub-Saharan Africa in world trade?" Discussion Paper, no. 348. Washington, D.C.: World Bank.

Anderson, J., and J.P. Neary, 1992, “Trade reform with quotas, partial rent retention, and tariffs." Econometrica 60, 57-76.

Brander, J.A., and B.J. Spencer, 1984, “Tariff protection and imperfect competition.” In H. Kierzkowski, ed., Monopolistic Competition and International Trade. Oxford University Press.

Center for Global Trade Analyis, 1999, Global Trade, Assistance, and Protection: The GTAP 4 Data Package. West Lafayette: Purdue Research Foundation.

Clyde, P.S. and J.D. Reitzes, 1995, "The effectiveness of collusion under antitrust immunity." United States Federal Trade Commission, Bureau of Economics Staff Report, December.

Deakin, B.M., and T. Seward, 1973, Shipping Conferences: A Study of Their Origins, Developments, and Economic Practices. Cambridge: Cambridge University Press.

Finger, J.M., 1983, “Policy research.” Journal of Political Economy 89(6), 1270-71.

Francois, J.F., and H.K. Hall, 1997, "Partial equilibrium modelling," In J.F. Francois and K.A. Reinert, eds., Applied Methods for Trade Policy Analysis: A Handbook. New York: Cambridge University Press, chapter 5.

Francois, J.F., and A. Strutt, 1999, "Post Uruguay Round tariff vectors for GTAP version 4." Tinbergen Institute, mimeo.

Francois, J.F., and I. Wooton, 2000, 'Intermediation Chains and International Trade. In preparation. 
Getzler, L., 1997, The Welfare Effects of International Trade Policy: Distance and Transportation Costs Make a Difference. Madison: University of Wisconsin dissertation.

Heaver, T.D., 1973, "The structure of liner freight rates." Journal of Transport Economics and Policy 4, 257-265.

Household Goods Forwarders Association, 1998a. "Maritime/ocean shipping: conferences: still alive and well." The Portal Online (internet publication) http://www.hhgfaa.org/feb_98, February.

Household Goods Forwarders Association, 1998b. "Maritime/ocean shipping: shipping reform and shippers associations." The Portal Online (internet publication) http://www.hhgfaa.org/oct_98, October.

Hufbauer, G.C., and K.-A. Elliott, 1994, Measuring the Costs of Protection in the United States. Washington, D.C.: Institute for International Economics.

Hummels, D., 1999, "Transportation costs and international integration in recent history." Mimeo, University of Chicago, February.

Koopmans, T., 1939, Tanker Freight Rates and Tankship Building, An Analysis of Cyclical Flucutuations. Netherlands Economic Institute report no. 27. Haarlem: De Erven F. Bohn N.V.

Lloyd, P.J., and A.G. Schweinberger, 1988, "Trade expenditure functions and the gains from Trade.” Journal of International Economic 24(3/4), 275-97.

Martin, W., 1997, "Measuring welfare changes with distortions.” In J.F. Francois and K.A. Reinert eds., Applied Methods for Trade Policy Analysis: A Handbook, New York: Cambridge University Press, chapter 3.

Sjostrom, W., 1989, "Collusion in ocean shipping: A test of monopoly and empty core models." Journal of Political Economy 97, 1160-1179. 
Sjostrom, W., 1992, "Price discrimination by shipping conferences." Logistics and Transportation Review 28, 207-216.

Talley, W.K., and J.A. Pope, 1985, "Determinants of liner conference rates under containerization.” International Journal of Transport Economics 12, 145-155.

Tinbergen, J., 1959, “Tonnage and freight.” In Jan Tinbergen Selected Papers, L.H. Klassen et al. eds., Amsterdam: North-Holland Publishing Company.

United Nations Conference on Trade and Development, 1992, Review of Maritime Transport. Geneva: UNCTAD.

United Nations Conference on Trade and Development, 1975, United Nations Conference of Plenipotentiaires on a Code of Conduct for Liner Conferences. Volume II, Final Act, TD/CODE/13/Add.1. New York: United Nations Publications.

United States Department of Transportation Maritime Administration, 1998, A Report to Congress on U.S. Maritime Policy. Washington: USDOT, May.

United States International Trade Commission, 1993, The Economic Effect of Significant U.S. Import Restraints. Washington: USITC publication 2699.

Veenstra, A.W., 1999, Quantitative analysis of shipping markets. Delft: Delft University Press.

Wegge, L.-L., 1993, "International transportation in the Heckscher-Ohlin model." In H. Herberg and N.V. Long eds., Trade, welfare, and economic policies: Essays in honor of Murray C. Kemp.\Studies in International Trade Policy. Ann Arbor: University of Michigan Press: 121-42. 
Figure 1. Effects of market share

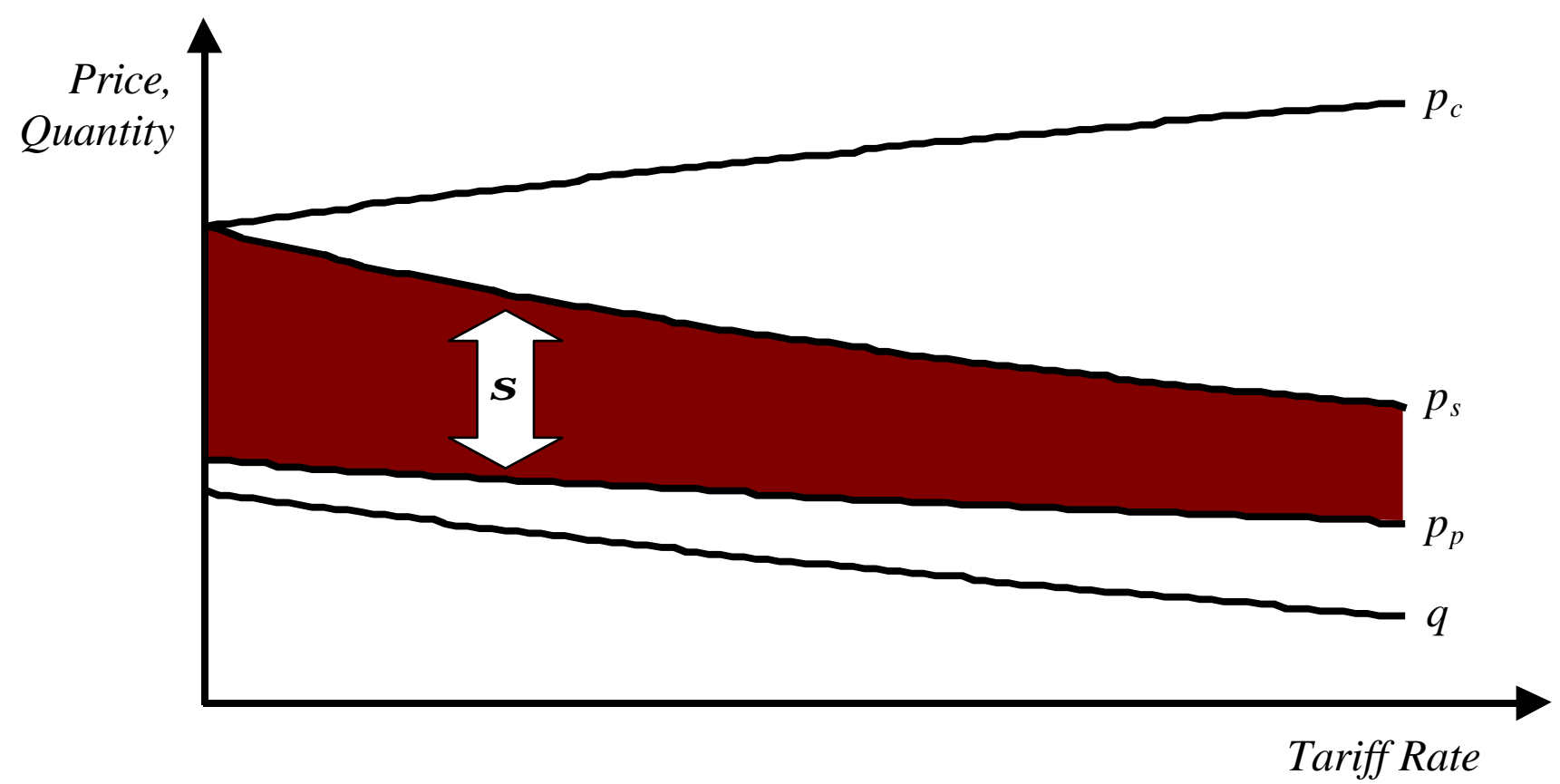

Figure 2. Effects of trade liberalization

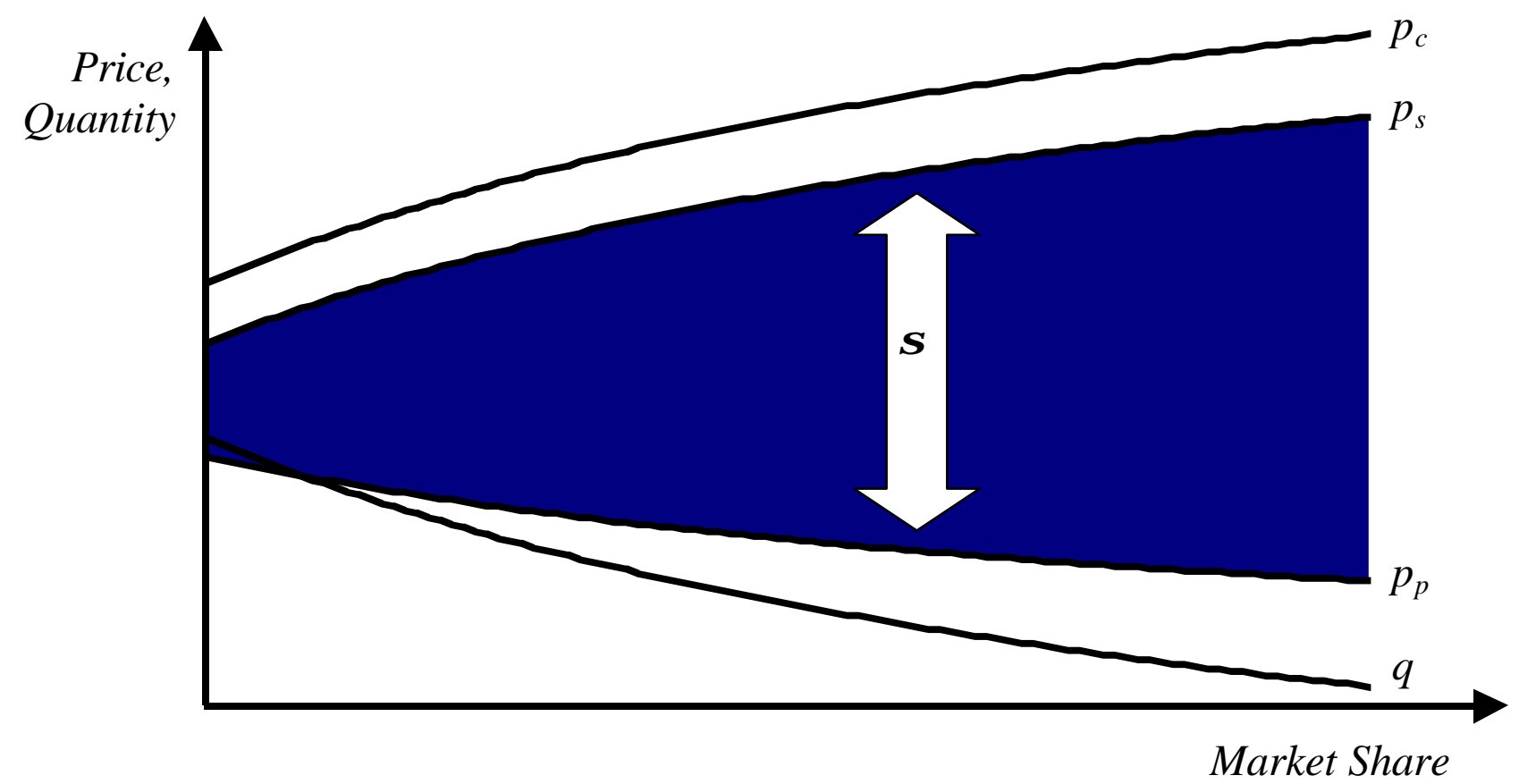


Figure 3. Shipping margin

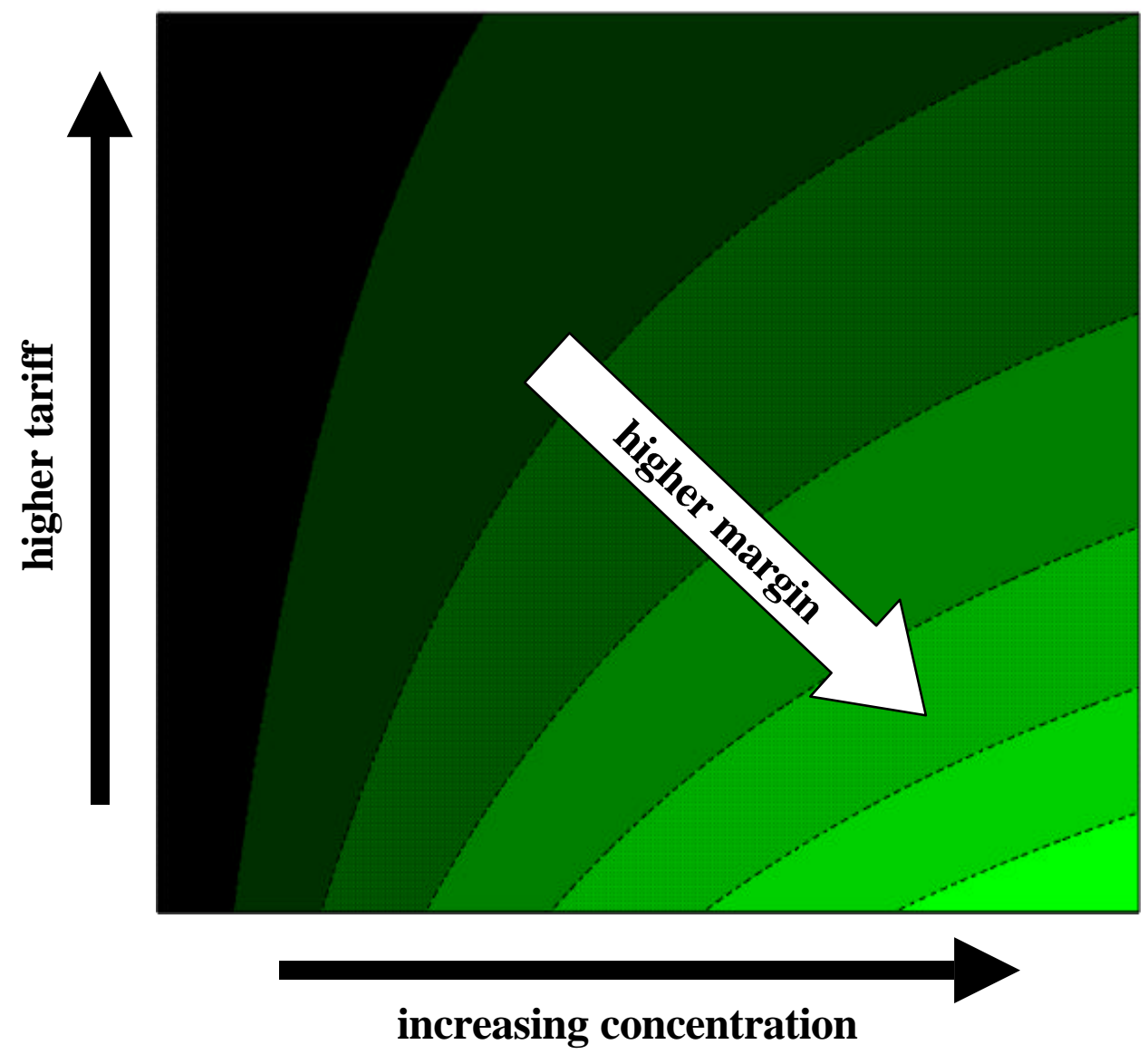

Table 1. Trade and income data

\begin{tabular}{|c|c|c|c|}
\hline & \multicolumn{3}{|c|}{ Stylized regional developing economies } \\
\hline & $\begin{array}{l}\text { Sub-Saharan and } \\
\text { Southern Africa }\end{array}$ & Latin America & South Asia \\
\hline \multicolumn{4}{|l|}{ values as percentages of GDP } \\
\hline GDP & 100.0 & 100.0 & 100.0 \\
\hline Exports (f.o.b.) & 23.6 & 10.4 & 12.8 \\
\hline Exports (c.i.f.) & 24.9 & 11.0 & 13.4 \\
\hline Imports (f.o.b.) & 23.7 & 11.9 & 14.5 \\
\hline Imports (c.i.f.) & 24.6 & 12.4 & 15.0 \\
\hline Tariff revenue on exports & 1.2 & 0.6 & 0.9 \\
\hline \multicolumn{4}{|l|}{ percentages } \\
\hline Tariff on exports in export markets & 4.9 & 5.2 & 6.4 \\
\hline Export tax equivalent of shipping margins & 9.6 & 10.1 & 9.1 \\
\hline \multicolumn{4}{|l|}{ point estimates } \\
\hline Demand elasticity for exports & -10.0 & -10.0 & -10.0 \\
\hline Export supply elasticity & 3.5 & 3.5 & 3.5 \\
\hline
\end{tabular}

Source: trade and GDP data are taken from the GTAP version 4 dataset. 
Table 2. Effects of trade liberalization

A. Income effect of trade liberalization (indexed to perfect competition)

\begin{tabular}{|c|c|c|c|c|c|c|}
\hline \multirow{2}{*}{$\begin{array}{l}\text { Stylized regional } \\
\text { developing economies }\end{array}$} & \multirow{2}{*}{$\begin{array}{c}\text { perfect } \\
\text { competition }\end{array}$} & \multicolumn{4}{|c|}{ number of firms } & \multirow{2}{*}{ monopoly } \\
\hline & & $n=10$ & $n=5$ & $n=4$ & $n=2$ & \\
\hline $\begin{array}{l}\text { Sub-Saharan \& } \\
\text { Southern Africa }\end{array}$ & 100.0 & 90.8 & 83.3 & 80.0 & 72.6 & 51.6 \\
\hline Latin America & 100.0 & 90.7 & 83.2 & 79.9 & 75.0 & 51.4 \\
\hline South Asia & 100.0 & 90.5 & 82.8 & 79.5 & 74.5 & 50.8 \\
\hline
\end{tabular}

B. Effect of trade liberalization on exports (percentage change)

\begin{tabular}{|c|c|c|c|c|c|c|}
\hline \multirow{2}{*}{$\begin{array}{l}\text { Stylized regional } \\
\text { developing economies }\end{array}$} & \multirow{2}{*}{$\begin{array}{c}\text { perfect } \\
\text { competition }\end{array}$} & \multicolumn{4}{|c|}{ number of firms } & \multirow[b]{2}{*}{ monopoly } \\
\hline & & $n=10$ & $n=5$ & $n=4$ & $n=2$ & \\
\hline $\begin{array}{l}\text { Sub-Saharan \& } \\
\text { Southern Africa }\end{array}$ & 31.8 & 29.2 & 27.0 & 26.1 & 22.2 & 17.5 \\
\hline Latin America & 33.5 & 30.8 & 28.5 & 27.5 & 26.0 & 18.4 \\
\hline South Asia & 41.4 & 38.0 & 35.2 & 33.9 & 32.1 & 22.7 \\
\hline
\end{tabular}

C. Effect of trade liberalization on shipping prices (percentage change)

\begin{tabular}{|c|c|c|c|c|c|c|}
\hline \multirow{2}{*}{$\begin{array}{l}\text { Stylized regional } \\
\text { developing economies }\end{array}$} & \multirow{2}{*}{$\begin{array}{c}\text { perfect } \\
\text { competition }\end{array}$} & \multicolumn{4}{|c|}{ number of firms } & \multirow{2}{*}{ monopoly } \\
\hline & & $n=10$ & $n=5$ & $n=4$ & $n=2$ & \\
\hline $\begin{array}{l}\text { Sub-Saharan \& } \\
\text { Southern Africa }\end{array}$ & 0.0 & 4.6 & 8.5 & 10.2 & 12.7 & 25.5 \\
\hline Latin America & 0.0 & 4.6 & 8.5 & 10.2 & 12.7 & 25.5 \\
\hline South Asia & 0.0 & 6.3 & 11.6 & 13.9 & 17.4 & 34.7 \\
\hline
\end{tabular}

